УДК 821.111'27

DOI: 10.18523/2616-8502.2019.2.13-19

Olena Moiseyenko

https://orcid org/0000-0002-6262-9678

\title{
UNTRANSLATABLE GERMAN WORD SCHADENFREUDE IN ENGLISH MEDIA DISCOURSE IN THE CONTEXT OF THE WORLD ENGLISHES PARADIGM
}

This paper aims to consider the aspects of conceptual integration and contextual usage of the German word 'schadenfreude' in the English Internet discourses of the leading media of Great Britain, the United States of America, the Independent State of Papua New Guinea, New Zealand, and Kenya published in 20182019. The results of the study suggest that a local culture exerts influence on the process of conceptual integration of a loanword in a particular variant of English.

Keywords: loanword, media discourse, varieties of the English language, context, conceptual integration

\section{Introduction}

Over the last decades, the field of linguistics witnessed a number of major and remarkable evolutions. The World Englishes paradigm is among them. There has been a substantial change in the approaches to English studies; a paradigm shift began in the early 1980s. English is spoken today on all five continents. The term World Englishes may comprise all the varieties of English including British and American English (Wolf, Polzenhagen, 2009). Various branches of linguistics recognize and describe the remarkable spread of English worldwide. Common denominator of World Englishes studies is their focus on the local identities of the various regional varieties of English (Kachru, Smith, 2008).

The most frequently encountered product of cultural contact is the set of loanwords that follow from intercultural communication. Loanword is defined as " $a$ word adopted from a foreign language with little or no modification" by the online Oxford English dictionary (Loanword. In online Oxford English dictionary, 2019). The rich variety of the English vocabulary reflects the vast number of words it has taken from other languages (Durkin, 2014).
The loanwords from German have also been the object of research. J. Schultz considers the German influence on the English lexicon in the twentieth century (Schultz, 2016). But the issue of the conceptual integration of loanwords, which are the results of the contact of languages and cultures, in different varieties of English which function in a variety of cultural spaces, has been left unnoticed by researchers. In the context of the multilinguacultural situation, the specific cognitive space is created, and the cognitive contact of different pictures of the world becomes inevitable in the mind of a multilingual speaker. This paper aims to consider the aspects of the conceptual integration and contextual usage of the German word schadenfreude in English Internet discourses of the leading media of Great Britain, the United States of America, the Independent State of Papua New Guinea, New Zealand, and Kenya published in 2018-2019.

The Online Oxford English Dictionary defines noun schadenfreude as "pleasure derived by someone from another person's misfortune" and explains its origin in the following way: German Schadenfreude, from Schaden "harm" + Freude "joy" (Schadenfreude. In Online Oxford English Dictionary, 2019). 
The Online Dictionary by Merriam-Webster defines schadenfreude as "enjoyment obtained from the troubles of others" (Schadenfreude. In the Online Dictionary by Merriam-Webster, 2019). It mentions that schadenfreude is often capitalized. The Dictionary by Merriam-Webster names schadenfreude among eight truly untranslatable German words which accept no substitutes. The other seven words are wetschmerz (the feeling of sentimental sadness or pessimism), schwarmerei (excessive and unbridled enthusiasm or sentiment), doppelgänger (the spirit duplicate of a living person), poltergeista (a ghost held to be responsible for unexplained noises (such as rappings)), schwarmerei (excessive and unbridled enthusiasm or sentiment), foosball (a table game resembling soccer in which the ball is moved by manipulating rods to which small figures of players are attached), kindergarten (a school for children usually aged four to six years old), and flank (antiaircraft guns) (8 Truly Untranslatable German Words. In Online Dictionary by Merriam-Webster, 2019).

Schadenfreude is placed among seven emotions that English does not have a word for on the website of the Online Oxford English Dictionary (Whiting, 2015). The other emotions are waldeinsamkeit (woodland solitude), esprit de l'escalier (wit of the staircase: repartee thought of only too late, on the way home), schlimazela (consistently unlucky, accident-prone person, a born loser) dépaysement (feeling that specifically arises when you are not in your home country), duende (something magical or enchanting), and torschlusspan$i k$ (last-minute panic) (Whiting, 2015).

T. Smith, a cultural historian, points out that many nations have a word for the emotion of schadenfreude. The French speak of joiemaligne, a diabolical delight in other people's suffering. The Danish talk of skadefryd, and the Dutch of leedvermaak (Smith, 2018). The Ukrainian language has the word zlovtikha to express enjoyment obtained from the troubles of others.

Schadenfreude, enjoyment obtained from the troubles of others, is recognized to be a common experience and an emotion which is inherent to social being. It is a comparison-and-justice based emotion (Dijk, Ouwerkerk, 2014).

T. Smith stresses that English has never really had a word for that feeling in English. According to T. Smith in 1926, a journalist in The Spectator, asserted that there was no English word for schadenfreude because there was no such feeling in their culture. T. Smith argues that enjoyment obtained from the troubles of others is a part of the British culture (Smith, 2018).

According to the Online Dictionary by Merriam-Webster, the word schadenfreude was in use in the mid-1700s in Germany, where it appears in a few books with tales intended for children. Early ci- tations for the word in English indicate that schadenfreude was thought to be a shameful defect first of Germans, and then of humanity in general. The feeling was unworthy, and therefore so was the word. Schadenfreude was favoured mostly among English-speaking academics until the early 1990s when it was introduced to more general audiences by The Simpsons. In an episode aired in October, 1991, Lisa explains what schadenfreude is to Homer, who is gloating at his neighbor's failure. According to the Online Dictionary by Merriam-Webster, after that episode aired, the steady increase was seen in the written use of schadenfreude in English (8 Truly Untranslatable German Words. In Online Dictionary by Merriam-Webster, 2019).

\section{Theoretical background}

Four major reasons why words are borrowed across languages were distinguished: the lack of the corresponding concept in the recipient language, the lack of the corresponding term in the recipient language, establishing a stylistic (or emphatic) effect, and establishing positive or negative connotations (Breiter, 1997). Many factors influence the amount and rate of borrowing. A relatively close contact over centuries in Europe and other areas resulted in extensive borrowing and re-borrowing. The advent of radio and television introduced another type of language and cultural contact in the spread of linguistic and communicative elements. The globalization of markets for products from around the world has resulted in advertisements which often carry not only foreign names but foreign terms.

Four stages in the integration process were described: a foreign word is first used by a certain group of recipient language speakers (for example scientists) in a certain domain (for example applied sciences) with a specific meaning. In this first stage the foreign word is not yet a loanword but a word from another language that is considered a foreign element in the recipient language. These words are often printed in italics or enclosed in quotation marks to indicate this foreignness. In the second stage the foreign word is used by a wider public and in other, less specific domains. From this stage on, the word becomes a loanword, even though it still is a foreign word, which often deviates from the sound, spelling, or the word formation pattern of the recipient language. In the third stage the loanword can become a part of the standard language as a result of the frequent usage, and it can be adapted to fit the recipient language's sound, spelling, and the word formation patterns. Foreign suffixes, for example, can be replaced by the common recipient language suffixes. The more a loanword is used, 
the more it will change to reflect the grammar of the recipient language. The last stage in the integration process implies that the word is no longer regarded as a loanword but as a native word (Sijs, 2009).

\section{Methods}

Two media websites from each country were selected to analyze the media discourse of Great Britain, the United States, and Kenya; one media website, the only available, was examined to analyze the media discourse of the Independent State of Papua New Guinea; and one news website which hosts several New Zealand newspapers was studied. The corpus includes articles published between January 2018 and February 2019. To identify the articles which contain the word schadenfreude, and to analyze the contexts of schadenfreude, the keyword search was used. The corpus of media websites includes:

- the British Broadcasting Corporation (BBC);

- the British newspaper The Sun;

- the Cable News Network (CNN) (the United States of America);

- the newspaper The Washington Post (the United States of America);

- the newspaper The National (Papua New Guinea);

- the news website Stuff. co. $n z$ (New Zealand);

- the newspaper The Star, Kenya;

- the news website Kenya Today.

\section{Results and discussion}

\section{Conceptual integration and contexts of use of the German word Schadenfreide in World Englishes media discourses}

The analysis of the media discourse shows that schadenfreude is perceived as a powerful and conceptualizing word:

The English language can be adaptable and expressive, but there are some concepts we just don't have a word for. And that's where borrowing from other languages can help...

\section{Schadenfreude}

The most well-known of these wonderful conceptualising foreign words is basically now a part of the English language too. Schadenfreude comes from the German words for harm (or damage) and joy. And as anyone who has laughed at someone getting their comeuppance will probably know, it means getting pleasure from someone's else's misfortune (Stuff, 24/04/2017).

...Spare a thought for these poor people who are DEFINITELY having a worse day than you... Schadenfreude can be a very powerful thing...IF you've got a touch of the Monday blues, you'll be glad to hear you're not the only one having a rough time. We're not one to advocate deriving pleasure from someone else's pain, but having said that, schadenfreude can be a very powerful thing... (The Sun, 24/09/2018).

The emotion of schadenfreude can still cause concerns, even shame in the cultural context of Great Britain. In January 2019, BBC aired the program devoted to the emotion of schadenfreude:

Schadenfreude: Why do we feel joy at another's pain?

Cultural historian and author Tiffany Watt Smith says we shouldn't feel ashamed to feel a sense of schadenfreude (BBC, 04/01/2019).

In June 2018, schadenfreude was chosen a word of the week by the Word Watch on the website of the Online Oxford English Dictionary (Kelly, 2018). Schadenfreude became one of the key words used in media in the context of World Cup 2018:

Many viewers weren't rattling any lozhkas at the shock defeat. Nor were they speechless like the Deutsche players and fans post-match. No, many a headline writer and tweeter took, cheekily, to the German language itself: Schadenfreude, they felt of the Teutonic titans, or the pleasure derived by someone from another's misfortune (BBC, 28/06/2018).

\section{Newspaper headlines: "Schadenfreude"} and "worst" Brexit deal

Photographs of tearful and bewildered German football fans are abundant in the papers, but sympathy is in short supply.

"Gott im Himmel!' crows a delighted Daily Mail, adding "in Britain, there's not a dry eye in the house!"

"Don't mention the score..." quips the Independent, channelling Basil Fawlty.

The Sun's newspaper's headline asks: "What's the German for Schadenfreude?"

The Daily Telegraph admits that it's cruel to revel in the misfortune of others. But it says England's World Cup anguish at German hands is stitched in history "like a black thread - and for once all that accumulated misery switched sides" (BBC, 28/06/2018).

The word schadenfreude is used with the reference to its German origin in the context of World Cup 2018:

The Sun's newspaper's headline asks: "What's the German for Schadenfreude?" (BBC, 28/06/2018).

Southgate could be forgiven a little schadenfreude after seeing Germany eliminated...

Twenty-two years after the most infamous moment of his playing career, Gareth Southgate could have been forgiven for feeling what the Germans call "schadenfreude" - a joy in the misery of others (The Sun, 28/06/ 2018).

The fact that fans of football teams can experience the sense of schredanfreude when the competitors 
of their team miss a goal has been proved by the scientific experiment: in a laboratory in Würzburg in Germany in 2015, thirty-two football fans agreed to have electromyography pads attached to their faces, which would measure their smiles and frowns while watching TV clips of successful and unsuccessful football penalties by the German team, and by their arch-rivals, the Dutch. The psychologists found that when the Dutch missed a goal, the German fans' smiles appeared more quickly and were broader than when the German team scored a goal themselves (Smith, 2018).

The examination of the British media discourse showed that the word schredanfreude is also used in the political and educational contexts:

\section{DEAR GERMANY}

Beckenbauer, Beck's, Bosch, BMW, Brahms, bratwurst... we LOVE you too, Germany. But we still want Brexit...

Call it schadenfreude, if you like. Our homes are grateful for your Bosch dishwashers, your Miele vacuums and your DeWalt drills.

Our Premier League is grateful for the creative genius of Jurgen Klopp and the talents of Leroy Sane. And our wallets are thankful for Aldi and Lidl's budget-friendly delights which fill our cupboards. Even our beloved Queen is a little bit German (The Sun, 23/01/ 2019).

...If Angela Merkel was perturbed by the terrible performance of her coalition partners at the $B a-$ varian ballot box, she was showing no sign of it as she addressed the association of foreign traders in Berlin.

Mrs Merkel may have even enjoyed a brief moment of schadenfreude as the crushing extent of the CSU's losses became clear (BBC, 15/10/2018).

White House lawn sinkhole spawns swamp jokes

Inevitably, the White House sinkhole quickly got its own Twitter account.

President Trump's supporters were less impressed with the sudden outpouring of digital schadenfreude from their political opponents (BBC, 23/05/2018).

Teachers and students post amusing back-toschool memes on first day after summer holidays....

Teachers might also need some injection of humour at the prospect of keeping control of hordes of pupils.

Whether you're experiencing fear, apathy or are secretly looking forwarding to hitting the books, these memes could ease the return.

Take some time out from your homework and experience the joy of Schadenfreude... (The Sun, 03/09/2018).

The concept of schadenfreude also causes concerns in the cultural context of the United States. According to $\mathrm{Ch}$. Grimaldi schadenfreude is not compatible with the values of the American society: “...What I find interesting is that no such word or phrase exists in American English. Certainly, there is no piecing together "shame" and "joy" to make "shamejoy," as in German. Shame and joy are antithetical, distant, never meant to share the same bed. That is because schadenfreude does not square with America's national obsession with the comeback story. Sure, we snicker along with the rest of the world when others stumble, but our culture is built on possibility. Here, the harder you fall, the greater the potential to get the hell back up - at least in theory. What is it about American history that distinguishes our reaction to schadenfreude? The exceptionalism that so many of us believe is our birthright. Every student wants an A, but not if that means the entire class gets one, Portmann says..." (Grimaldi, 2014). At the same time, Ch. Grimaldi admits: "To the contrary, the concept of schadenfreude is no more German than it is American or any other nationality. It's an automatic human response that the Germans simply have managed to name more efficiently than the rest of us. Even Lopez says he succumbs to an occasional flare-up when other people's musicals get bad reviews, which is an awful thing to admit" (Grimaldi, 2014). She also indicates that "sporting events are arenas practically dedicated to schadenfreude" (Grimaldi, 2014).

Schadenfreude was used in the context of World Cup 2018:

World Cup 2018: Best moments of Russia 2018

\section{Schadenfreude}

The curse of the World Cup lived on.

Germany started the tournament as reigning champion and much fancied to successfully defends its crown. But the Germans failed to make it to the knockout stages, finishing bottom of its group after defeats by Mexico and South Korea, and became the third straight reigning champions to be knocked out in the group stage - following Italy and Spain... The world reacted with one word: Schadenfreude. The German noun for "joy derived by someone from someone's misfortune" took social media by storm. Brazil's Fox Sports couldn't hide its glee, given that the Germans beat Brazil 7-1 four years ago, filling its character limit on Twitter with "ahaha" (CNN, 16/07/2018).

"Schadenfreude": The world reacts to Germany's shock exit

Germany's World Cup dreams are officially over and the world reacted in one word: Schadenfreude.

The German noun for "joy derived by someone from someone's misfortune" took social media by storm as Germany became the fourth casualty of the infamous "Champion's Curse" of the holder being knocked out at the first hurdle in the following tournament. 
In a dismal performance, Germany lost 2-0 to South Korea Wednesday to crash out, enabling a jubilant Mexico to qualify despite losing 3-0 to Sweden (CNN, 28/06/2018).

On February 3, 2019 schadenfreude was chosen the Word of the Week by the humorous newspaper Chicago Shady Dealer of the University of Chicago. Schadenfreude is used in the context of a sport event:

Schadenfreude is pronounced shah-den-Freuduh and is a noun. An example of it used in a sentence is «watching those Patriots fans drag their sad little feet out of Mercedes-Benz Stadium filled me with a profound sense of schadenfreude». I get schadenfreude just thinking about Bill Belichick coming home from a Super Bowl empty-handed for the second time in a row. They're the Kobra Kai Dojo of the NFL, with Brady as their weisenheimer Billy Zabka, and I'm waiting in delicious anticipation for their ego to get kicked right in the jaw (Chicago Shady Dealer, 03/02/2019).

Schadenfreude is widely used in other contexts such as politics, style, and business:

Many Americans think that climate-change deniers "get what they deserve» when disasters strike ...Why would people feel that particular kind of schadenfreude, concluding that others deserve to have their... (The Washington Post, 24/01/2019).

Black voters struggle with racism in both the Democratic and Republican parties... Democrats wore blackface seems like schadenfreude. For two generations, Democrats have held a ... (The Washington Post, 09/02/2019).

Ask Amy: Insecurities are triggered by old acquaintance ... irrationally solicits strong feelings of jealousy or schadenfreude. Social media can more or less «weaponize» these... (The Washington Post, 09/02/2019).

It's not enough for Facebook to own your images. It wants to own your mortality, too ...encourages malice and feeds our appetite for schadenfreude (The years haven't been kind to him...)... (The Washington Post, 16/01/2019).

Billionaire Pays the Price for His General Electric Ambush ...sparring partners will naturally feel a little schadenfreude about its roughly 100 million-euro (\$114-million... (The Washington Post, 04/01/2019).

According to the research of S. Nachman, among the Melanesians of Nissan Atoll in Papua New Guinea, laughter and humor may occur as expressions of schadenfreude. Gossip and storytelling, in particular, offer occasions for such expressions (Nachman, 1986). T. Smith also describes the culture of schadenfreude of the Melanesians who live in
Papua New Guinea, where laughing at other people's pain is known as Banbanam. At its most extreme, it involves taunting a dead rival by exhuming their corpse and scattering the remains around the village. More of an everyday sort of Banbanam is gloating at someone's humiliating failure behind their back - as when the rival villagers' feast day is rained on because their Weather Magician's spells fail, or a wife grabs her cheating husband by the testicles and ignores his pleas for mercy. Banbanam is a kind of resistance too. Melanesians still enjoy telling the story of how an Australian government minister visited the village, got annoyed because the villagers would not do what he wanted, drove away in a huff and crashed into a tree (Smith, 2018).

The Independent State of Papua New Guinea, linguistically, is the world's most diverse country, with more than 700 native tongues. Major languages are English, Tok Pisin, and Hiri Motu. Although the anthropological studies show the existence of the culture of schadenfreude the examination of the current media discourse of the leading internet newspaper The National (Papua New Guinea) showed no results of the usage of the word schadenfreude.

On the contrary, the examination of the English media discourse of New Zealand, which is also a Pacific nation, shows wide usage of the word schadenfreude although schadenfreude is deeply repressed within their culture for its primitive and often cruel nature according to J. Balchin. In spite of the fact that there are two cultural groups in New Zealand: New Zealanders of European descent; and the Maori, the descendants of Polynesian settlers, J. Balchin unites two cultures and says our culture:

Although the English language does not have a word for it, schadenfreude is undoubtedly an emotion we recognise. While schadenfreude is deeply repressed within our culture for its primitive and often cruel nature, one might argue that increased awareness of schadenfreude will help us to be more compassionate and sensitive (Balchin, 2016).

In the cultural context of New Zealand as well as in the contexts of Great Britain and the United States the emotion of schadenfreude is recognized to be natural in sport events:

One of the greatest satisfactions in sport is watching your mate's team lose. The bigger the occasion, the better it gets.

The ultimate working definition of schadenfreude, a sulky petulant reaction it may be but also one that undeniably provides some small ray of sunshine to dull the pain caused by your own hapless bunch of losers doing what they do best-and that's break your stupid sporting heart...It's also 
one of the best feelings in sport. I admit it... (Stuff, 20/12/2018).

Schadenfreude is also used in a variety of other contexts such as politics, lifestyle, business, and entertainment:

Responsible investors can be forgiven for experiencing more than a little schadenfreude over Johnson \& Johnson's tumble on US markets before Christmas (Stuff, 09/01/2019).

He has gathered a horde of enemies. Some have taken his strokes as schadenfreude. One blog simply called it karma (Stuff, 22/01/2019).

As an inveterate gym rat, I can assure you that you will not find many people who possess the cosmic secrets to love and life satisfaction. (This might itself give you a little schadenfreude-induced jolt of joy) (Stuff, 19/01/2019).

Instead, as most everyone knows, Fyre was a disaster, becoming Instagram infamous for serving up «a tsunami of Schadenfreude», as one observer puts it. Most of Fyre's selfie-obsessed attendees, who'd paid thousands of dollars to attend, were stranded on a gravel spit with little food, water or shelter, and worst of all, spotty internet access. Their suffering was exquisite and, admittedly, a fine comeuppance (Stuff, 18/01/2019).

He insists he felt no moment of schadenfreude when Little's attempts to get Ngäpuhi back to the negotiating table failed following a vote this week (Stuff, 15/12/2018).

The Republic of Kenya is situated on the equator on Africa's east coast. Major languages are Kiswahili (official), English (official), various Bantu and Nilotic languages. The examination of current media discourse demonstrates a high degree of conceptual integration of schadenfreude in the cultural context of Kenya: the word schadenfreude is not capitalized and is used in a wider variety of contexts, especially in the context of personal relationships and personal attitudes. One of the readers of the newspaper The Star, Kenya writes on the emotion of schadenfreude in the culture of Kenya in his comments on the article "WYCLIFFE MUGA: Why some Kenyans like Trump":

...And it is a warped psychological behavior that is very prevalent among members of our own families (unhealthy sibling rivalry), including so called "extended family" (proverbial relatives and beholders of «crocodile tears» in their midst), as well as crowds in the villages, sub-clans, clans, sub-tribes, tribes («race»), et al. who are still so much attached and addicted to "armchair malice» (The Star, Kenya, 15/11/2018).
The examples of the usage of the word schadenfreude in Kenyan media discourse include:

Stars would be the biggest beneficiaries should the Sierra Leone results be removed as the West African nation had beaten them 2-1 in the opening group game. That would obviously be refuted by the national team as it would seem a case of schadenfreude on a sporting opponent (The Star, Kenya, 12/10/2018).

And her online breakup with the guy, and namecalling has been received with glee. Because, her success on TV, makes her a product of so much gossip, jealous and schadenfreude (Kenya Today, 26/12/2018).

I can understand the overt schadenfreude in many people after a photo of a dishevelled Kirubi surfaced. His chubby cheeks are gone, his conniving smile disappearing (Kenya Today, 26/12/2018).

\section{Conclusion}

The results of the analysis of the current discourses of Great Britain, the United States of America and New Zealand show that despite the usage of the German word schadenfreude in a wide range of contexts such as political events, in the contexts of business and entertainment, in the educational context, in societies there are still concerns as for the emotion of schadenfreude which is considered to be primitive and cruel by nature, which may contradict society values, and may cause shame. The natural context for schadenfreude is recognized to be a sport event. Schadenfreude can be used with reference to Germany, and can be capitalized. In spite of the results of the anthropological research on the existence of the culture of schadenfreude of the Melanesians who live in Papua New Guinea, the examination of the current media discourse of Papua New Guinea shows no results of the usage of the word. The examination of current media discourse demonstrates a high degree of conceptual integration of Schadenfreude in the cultural context of Kenya: the word schadenfreude is not capitalized, and is used in a wider variety of contexts, especially in the context of personal relationships and personal attitudes. The results of the study suggest that the process of the conceptual integration of the German word schadenfreude has not been completed and continues to evolve. Local culture exerts influence on the process of integration of a loanword, and the degree of integration is different in different varieties of English. This study offers prospects for future research on the conceptual relations of cultures and languages. 


\section{References}

Balchin J. Spilled Soup, Secrets \& Schadenfreude. Critic [Electronic resource] / J. Balchin. - Mode of access: https:/www.critic co.nz/features/article/5704/spilled-soup--secrets---schadenfreude. - Title from the screen.

Breiter M. What is the difference between "shashlyk" and "barbecue"? / M. Breiter // Perspectives: Studies in Translatology. 1997. - No. 5 (1). - P. 85-100.

Durkin Ph. Borrowed Words: A History of Loanwords in English / Ph. Durkin. - Oxford : Oxford University Press, 2014.

Grimaldi Ch. Glad I'm Not You. The morning news [Electronic resource] / Ch. Grimaldi. - Mode of access: https:// themorningnews.org/article/glad-im-not-you. - Title from the screen.

8 Truly Untranslatable German Words [Electronic resource]. In online dictionary by Merriam-Webster. - Mode of access: https://www.merriam-webster.com/words-at-play/untranslatable-german-words/schadenfreude. - Title from the screen.

Kachru Ya. Cultures, Contexts, and World Englishes / Ya. Kachru, L. E. Smith. - New York, NY : Routledge, 2008.

Kelly J. Weekly Word Watch: civility, poorface, and Schadenfreude [Electronic resource] / J. Kelly. - In online Oxford English dictionary. - Mode of access: https://blog.oxforddictionaries. com/2018/06/29/weekly-word-watch-civility-poorface-schadenfreude/. - Title from the screen.

Loanword [Electronic resource]. - In online Oxford English dictionary. - Mode of access: https://en.oxforddictionaries.com/ definition/loanword. - Title from the screen.
Nachman S. R. Discomfiting Laughter: "Schadenfreude" among Melanesians / S. R. Nachman // Journal of Anthropological Research. - 1986. - Vol. 42, No. 1. - P. 53-67.

Schadenfreude [Electronic resource]. - In online dictionary by Merriam-Webster. - Mode of access: https://www.merriam-webster.com/dictionary/schadenfreude. - Title from the screen.

Schadenfreude [Electronic resource]. - In online Oxford English dictionary. - Mode of access: https://en.oxforddictionaries.com/definition/schadenfreude. - Title from the screen.

Schadenfreude: understanding pleasure at the misfortune of others / W. W. van Dijk, J. W. Ouwerkerk (Eds.). - Cambridge : Cambridge University Press, 2014.

Schultz J. Twentieth-Century Borrowings from German to English: Their Semantic Integration and Contextual Usage / J. Schultz. Frankfurt am Main : Peter Lang publishing, 2016.

Sijs N. van der. Cookies, Coleslaw, and Stoops. The Influence of Dutch on the North-American Languages / N. van der Sijs. Amsterdam : AUP, 2009.

Smith T. W. Schadenfreude: The Joy of Another's Misfortune / T. W. Smith. - New York, NY : Little, Brown Spark, 2018.

Whiting T. 7 emotions that English doesn't have a word for [Electronic resource] / T. Whiting. - In online Oxford English dictionary. - Mode of access: https://blog.oxforddictionaries. com/2015/09/14/7-emotions-that-english-doesnt-have-a-wordfor/. - Title from the screen.

Wolf H.-G. World Englishes: A Cognitive Sociolinguistic Approach / H.-G. Wolf, F. Polzenhagen. - Berlin : Mouton de Gruyter, 2009.

\section{Моісеєнко Олена}

\section{БЕЗЕКВІВАЛЕНТНЕ НІМЕЦЬКЕ СЛОВО SCHADENFREUDE В АНГЛОМОВНОМУ МЕДІЙНОМУ ДИСКУРСІ В КОНТЕКСТІ ПАРАДИГМИ ШОRLD ENGLISHES}

Постановка проблеми. В умовах мультилінгвокультурної ситуації створюється певний когнітивний простір, у якому є неминучим когнітивний контакт різних картин світу в свідомості мультилінгвальних мовиів. Однак поза увагою дослідників залишається проблема концептуального інтегрування лексичних запозичень, які є результатом контактування мов та культур, у різні варіанти англійської мови, які функиіонують у різноманітних культурних просторах. Англійська мова не має еквівалента до німецького слова schadenfreude, яке означає «зловтіха», оскільки у британській та американській культурі довгий час заперечувалось існування такої емоиії. Слово schadenfreude набуває популярності в англомовному дискурсі тільки на початку 1990-х рр. після пояснення його значення в одному з епізодів серіалу «Сімпсони».

Мета статті. Метою статті є розгляд аспектів конщептуального інтегрування та контекстів використання слова schadenfreude у різних варіантах англійської мови.

Методи дослідження. Методи дослідження передбачають відбір та аналіз інтернет-статей з використанням слова schadenfreude в англомовних провідних медіа Великої Британії, США, Папуа Нової Гвінеї, Нової Зеландї та Кенії у період 2018-2019 рр.

Основні результати дослідження. Результати дослідження свідчать, що, попри використання schadenfreиdе у контекстах різних подій, у суспільствах все ще існують застороги до емоиії зловтіхи як такої, що має жорстоку та примітивну сутність, суперечить культурним цінностям і може викликати сором. Природним контекстом для вживання слова schadenfreude вважається спортивна подія. У медійному дискурсі Папуа Нової Гвінеї не засвідчено жодного використання слова schadenfreude. Медійний дискурс Кенії є прикладом більш високого ступеня кониептуальної інтеграиії німецького слова schadenfreude.

Висновки і перспективи. Локальна культура впливає на прочес конщептуального інтегрування запозичення в певний варіант англійської мови. Проведена розвідка відкриває перспективи подальших досліджень концептуальних взаємовідносин мов та культур.

Ключові слова: запозичення, медійний дискурс, варіанти англійської мови, контекст, концептуальна інтеграція. 